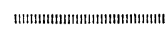 論 文 急冷凝固した鋳鉄と高炭素鋼の鋳片の特性

\section{Characteristics of Rapidly Solidified Cast Iron and High Carbon Steel}

\author{
Chisato Yoshida, Kazuyuki Taniguchi, Tomokazu Nakagawa, \\ Masatoshi Sudo and Teruhiko NozAKI
}

Synopsis:

After the energy crisis the steel industry is required to minimize its energy consumption. Direct connection with a hot rolling process in continuous casting is one of the solutions for this problem. Furthermore along with the developments of the continuous casting process, new casting processes are presently under development with the objective of eliminating most parts of the rolling and heating processes.

As the solidification rate of the rapidly solidified plate in the new casting processes is $10^{0} \sim 10^{3 \circ} \mathrm{C} / \mathrm{s}$, the properties of the cast plate are expected to be improved. As the first step in our experiment, the properties of cast iron and high carbon steel were investigated.

Thin sheets of cast iron were made by the twin roll test caster and cold rolling. Cold rolling was attainable due to the fine spheroidal graphite structure formed by the rapid solidification and the following annealing.

Furthermore, rapid solidification of high carbon steel was investigated by using the water-cooled chill block apparatus, which was supposed to function similarly to a caterpillar type caster. The rapid solidification promoted less macrosegregation and finer $\mathrm{MnS}$ inclusions.

It is well known that in the high carbon steel, the heat treatment is necessary for spheroidizing the cementite structure. It was proved, however, by the rapid cooling at eutectoid temperature, the spheroidal cementite structure was obtained in a relatively shortened annealing time.

\section{1. 緒}

言

鋼の連続鋳造から圧延までの工程の変遷は，工程省略 が主体であつた．現在は連続鋳造と圧延の直結化が行わ れているが，次の世代の工程は連続鋳造と圧延を一体化 したプロセスとなろら.

Table 1 は, 急冷凝固プロセスの分類表である. 方式 I は鋳片厚及が $20 \sim 50 \mathrm{~mm}$ 程度で, プロセスとして

Table 1. Classification of new casting process.

\begin{tabular}{c|c|c|c|l}
\hline & Casting & Thickness & Cooling rate & \multicolumn{1}{|c}{ Process } \\
\hline I & $\begin{array}{l}\text { Thin slab } \\
\text { casting }\end{array}$ & $20 \sim 50 \mathrm{~mm}$ & $10^{\circ} \sim 10^{{ }^{\circ} \mathrm{C} / \mathrm{s}}$ & $\begin{array}{l}\text { Twin belt } \\
\text { Chill block }\end{array}$ \\
\hline II & $\begin{array}{l}\text { Strip } \\
\text { casting-1 }\end{array}$ & $1 \sim 10 \mathrm{~mm}$ & $10^{2} \sim 10^{3{ }^{\circ} \mathrm{C} / \mathrm{s}}$ & $\begin{array}{l}\text { Twin roll } \\
\text { etc. }\end{array}$ \\
\hline III & $\begin{array}{l}\text { Strip } \\
\text { casting-2 }\end{array}$ & $<1 \mathrm{~mm}$ & $10^{4} \sim{ }^{\circ} \mathrm{C} / \mathrm{s}$ & $\begin{array}{l}\text { Single roll } \\
\text { Twin roll }\end{array}$ \\
\hline
\end{tabular}

は，双ベルト法やチルブロックを用いた方法が考えられ ている. 万式II鋳片厚みが数 $\mathrm{mm}$ で, 双ロール法が その代表的なものである. 方式は鋳片厚 みが $1 \mathrm{~mm}$ 以下で，単ロールや双ロール法で行われている.

溶鋼から直接数 $10 \mathrm{~mm}$ の薄スラブを製造することが できれば粗圧延工程を省略することができるし，溶鋼か ら直接数 $\mathrm{mm}$ 程度の薄鋳片が製造できれば仕上圧延工 程も省略できる. この時鋳片は, $10^{\circ} \sim 10^{3}{ }^{\circ} \mathrm{C} / \mathrm{s}$ の急冷凝 固により新しい材質的メリットが見出される可能性があ る. 急冷凝固プロセスとしては古くより数多くのアイデ アが提出されているが1)，材質に関する問題はまだ未解 決のものが多い2).

本研究では, 研究の第 1 段階として, 鋳鉄の急冷凝固 を双ロール法で行つた，これは Table 1 のIIに相当す る. 次に, 2 枚の水冷の 銅チルブロックの間に, 3〜40

昭和 60 年 10 月本会講演大会にて発表 昭和 61 年 1 月 10 日受付 (Received Jan. 10, 1986)

* (株) 神戸製鋼所 材料研究所工博 (Materials Research Laboratories, Kobe Steel, Ltd., 1-3-18

Wakinohama-cho Chuo-ku Kobe 651)

*2 (株) 神戸製鋼所 材料研究所 (Materials Research Laboratories, Kobe Steel, Ltd.)

*3 (株) 神戸製鋼所機械研究所 (Mechanical Engineering Research Laboratory, Kobe Steel, Ltd.)

*4 (株) 神戸製鋼所 技術情報企画部 (Technical Information \& Planning Department, Kobe Steel, Ltd.) 


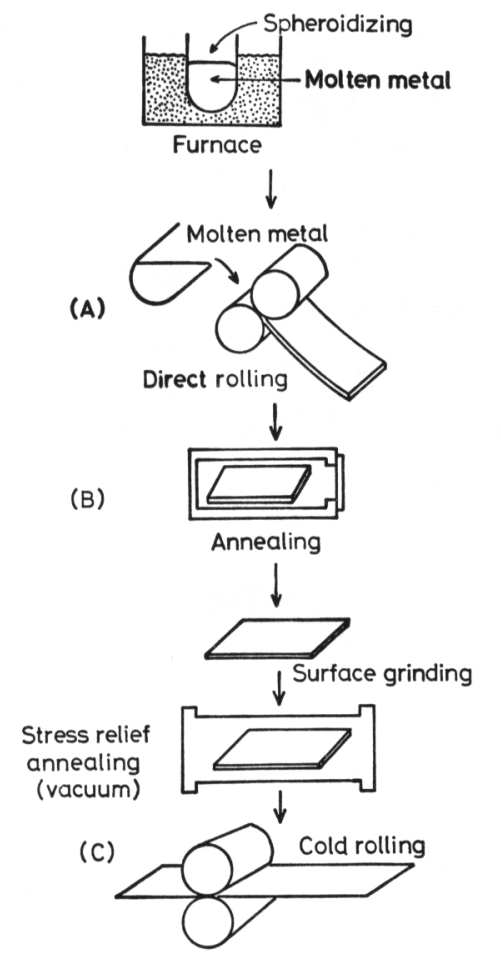

Fig. 1. Rolling process of ductile cast iron.

Table 2. Chemical composition of ductile cast iron $(\%)$.

\begin{tabular}{c|c|c|c|c|c}
\hline $\mathrm{C}$ & $\mathrm{Si}$ & $\mathrm{Mn}$ & $\mathrm{P}$ & $\mathrm{S}$ & $\mathrm{Mg}$ \\
\hline 3.4 & 2.4 & 0.12 & 0.06 & 0.016 & 0.03 \\
\hline
\end{tabular}

$\mathrm{mm}$ 厚の高炭素鋼を鋳造し, 鋳片の性質を調査した.こ れは，方式 I と II に相当する. 方式IIIの急冷薄帯は本研 究では行つていない.

\section{2. 鋳鉄を用いての双ロール実験}

鋳鉄は鋳物といら概念が強く, 板材等への適用の試 み3)はあまり行われていない，本実験では，実験室的規
模で，球状黑鉛鋳鉄溶湯を双ロールに鋳造し，1２ $\mathrm{mm}$ の板を作製し，さらにとの冷間圧延を行つた。

\section{$2 \cdot 1$ 実験方法}

Fig. 1 飞鋳鉄薄板の作製方法を示す. $15 \mathrm{~kg}$ の高周 波溶解炉で鋯鉄を溶製し，黒鉛球状化処理（球状化剂と して $1 \%$ の $\mathrm{Fe}-\mathrm{Si}-\mathrm{Mg}$ 合金を，接種剤として $0.4 \%$ の $\mathrm{Fe}-\mathrm{Si}$ 合金を置注法で添加）を行って Fig. 1 (A) の 双ロールに溶湯を鋳込んだ。双ロールは $150 \mathrm{~mm} \phi て ゙$, $260 \mathrm{~mm} l$ の鋼製の 水冷ロールで, 2 本のロールを 45 度の角度で斜めに配置した ${ }^{3)}$ 。ロール周速度は $5 \mathrm{~m} / \mathrm{min}$ $\sim 10 \mathrm{~m} / \mathrm{min}$ で, 初期ロール間隔は $1 \sim 2 \mathrm{~mm}$ である.

次に, (B) の黒鉛化焼鈍を電気炉で行い, (C) の冷 間圧延で約 $0.5 \mathrm{~mm}$ の薄板とした. 化学組成の一例を Table 2 亿示す.

\section{$2 \cdot 2$ 実験結果と考察}

\section{$2 \cdot 2 \cdot 1$ ミクロ組織}

Photo. 1 は (A) 双ロール鋳造後, (B) 黒鉛化焼鈍 後, (G) 冷間圧延後のミクロ組織写真である. 双口ルでは, 溶湯が急冷凝固されるためにせメンタイトとオ ーステナイト（常温ではフェライトとパーライトに変 化）の共晶である白銑組織となるが，これを黒鉛化焼鈍 すると, $20 \mu \mathrm{m}$ 以下の球状黒鉛が析出し, 黒鉛とフェラ イトの組織となる．冷間圧延をくり返して薄板とすると (G) の上うに黒鉛は偏平となる.

Photo. 1 (A) はデンドライト組織で, 表面部での 2 次アーム間隔は約 $7 \mu \mathrm{m}$ であつた. 岡本 ${ }^{4}$ とより求めら れている次式の 2 次アーム間隔と冷却速度の関係を急冷 域まで拡大して用いると冷却速度は約 $10^{3 \circ} \mathrm{C} / \mathrm{s}$ となつ た.

$$
\begin{aligned}
& d_{2}=340\left(\frac{1}{\% \mathrm{C}}-\frac{1}{4.3}\right)^{0.35} / v^{\mathbf{0 . 2} 28} \\
& d_{2}: 2 \text { 次アーム間隔 }(\mu \mathrm{m}) \\
& v: \text { 冷却速度 }\left({ }^{\circ} \mathrm{C} / \mathrm{min}\right)
\end{aligned}
$$

双ロールで鋳造した鋳鉄薄板の黒鉛化焼鈍実験を行つ た. 軟質で伸びの大さい、球状黒鉛鋳鉄を作製するには,

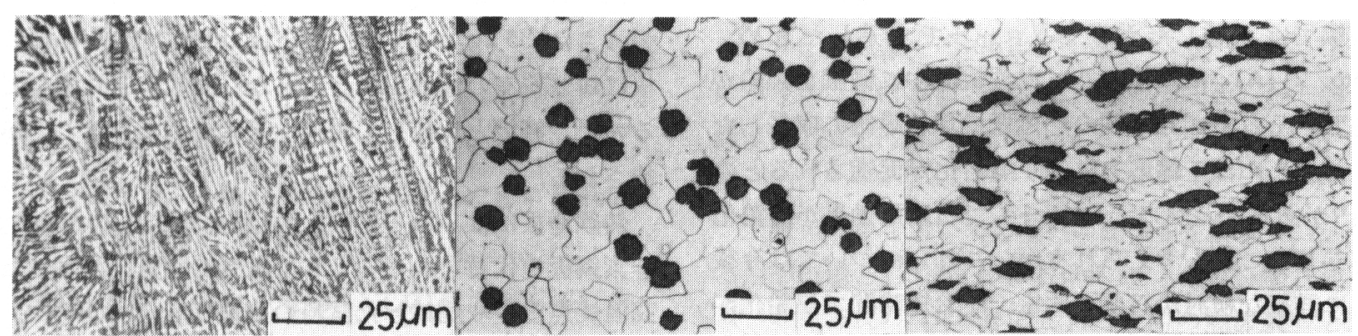

(A) Twin roll

(B) Annealing

(C) Cold rolling

Photo. 1. Micro structure. 


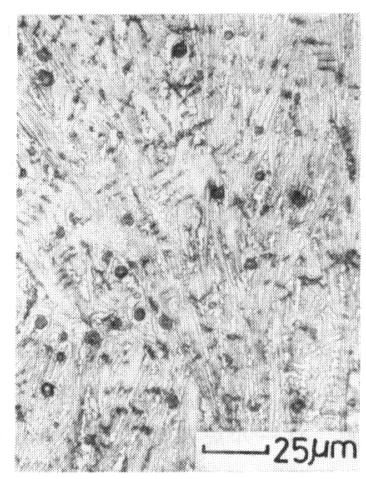

(A) Before annealing

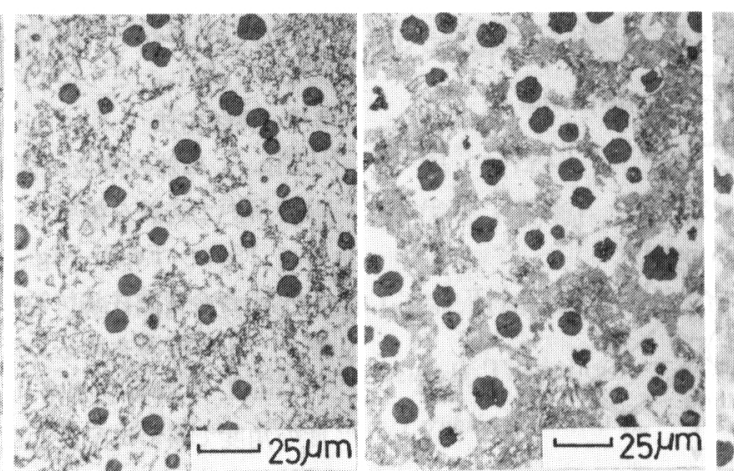

(C) $10 \mathrm{~min}$

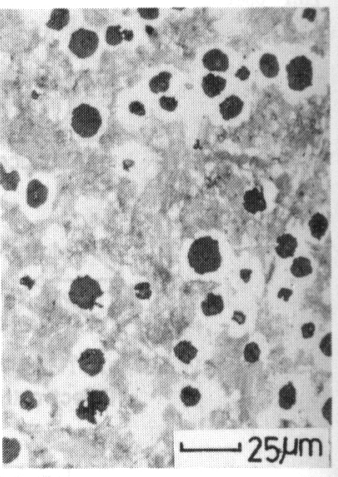

(D) $15 \mathrm{~min}$

Photo. 2. Change of micro structure by annealing at $900^{\circ} \mathrm{C}$.

$800 \sim 900^{\circ} \mathrm{C}$ のオーステナイト域で $2 \sim 3 \mathrm{~h}$ と 700 750 ${ }^{\circ} \mathrm{C}$ の共析変態域で $3 \sim 6 \mathrm{~h}$ 保持後炉冷または空冷でフ ェライト基地とすることが多(、5). Photo. 2 は $900^{\circ} \mathrm{C}$ に加熱した炉内に試料を所定時間保持した後冷却した実 験の結果である. Photo. 2 (A) は燒鈍前の白銑組織で ある. (B) は $5 \mathrm{~min}$ 保持した場合でセメンタイトのか なりの部分が黒鉛に変態しているが，まだ基地組織にセ

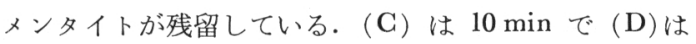
15 min 保持した場合で, $10 \sim 15 \min$ の保持で, (A) で みられたセメンタイトは分解して黒鉛とフェライトとパ ーライトの組織となつている. 次に基地組織とパーライ トからフェライトへの变態を調べた. $900{ }^{\circ} \mathrm{C}$ で完全にセ メンタイトを分解した試料を, $700^{\circ} \mathrm{C}$ で所定時間保持し た後泠却したところ，10 min 保持でフェライトになつ ていた. 以上の結果から， $900^{\circ} \mathrm{C}$ と $700^{\circ} \mathrm{C}$ でそれぞれ 10〜15 min 保持することで白銑組織が球状黒鉛とフェ ライトからなる組織に変態することがわからた，従つて 鋳鉄薄板は, 通常の球状黒鉛に比較してかなり短時間で 黒鉛化焼鈍が行われたことになる。

黒鉛化焼鈍が短時間で行われる理由として, 鋳鉄薄板 が急冷凝固されるため, セメンタイトのラメラー間隔が せまくなりセメンタイト溶解の際の炭素原子の拡散経路 が短くなることが考光られる6). その他の理由として, 本実験では接種した溶湯を双ロールで鋳造したため, Photo. 2 (A) に示すように白銑組織中に微細な黒鉛が 混在し, それらが短時間の熱処理で球状黒鉛に成長した こと,さらには圧縮応力により黒鉛化が促進されるとの 報告》があることから，双ロールでの压延効果が黒鉛化 に寄与したことも考兄られるが，これらについては今後 さらに詳細な検討が必要で西る.な短時間で黒鉛化が 行われる現象を利用すれば, Fig. 1 の（A）双ロール 之（B）セメンタイトの黒鉛化の工程を連続化させて,

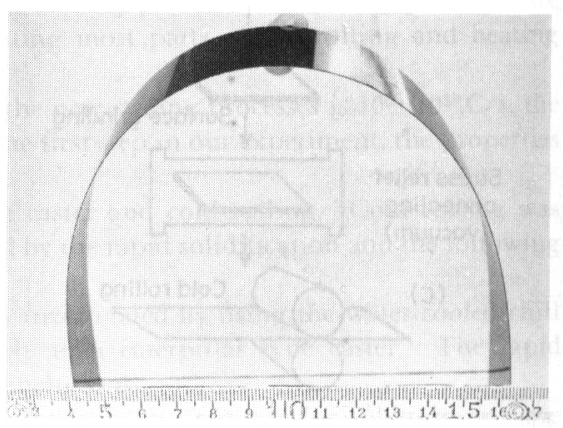

Photo. 3. Sheet of ductile cast iron by cold rolling.

延性のある鋳鉄薄板を溶湯から直接作製することが可能 となろら・

\section{$2 \cdot 2 \cdot 2$ 性質}

冷間圧延は中間焼鈍なしに約 20 パスで $2 \mathrm{~mm}$ 厚か ら $0.5 \mathrm{~mm}$ 厚とした. 圧下率は約 $75 \%$ まで可能であ つた. 冷間圧延を可能にしたのは，急冷凝固と熱処理に より, 球状黒鉛を微細に分散させたことと, 共晶セメン タイトを分解させたことである。

冷間圧延した鋳鉄薄板は, Photo. 3 に示すよらにわ ん曲させることができ, 若干の深絞りも可能である.こ れは従来の鋳鉄材料では得られなかつた性質である.引 張強さは $35 \mathrm{~kg} / \mathrm{mm}^{2}$ で, のびは $10 \%$ である. 鋳鉄薄 板は鋳鉄特有の性質を失うことなく薄板にしたものであ るので，鋼板と比較して耐候性等に優れていることが期 待される.

鋳鉄薄板には，2３\%の Si が含有されているので， 珪素鋼板の代替をねらいとして磁気的性質を測定した。 高温焼鈍と歪取焼鈍した試料の磁束密度 $B_{10}(10 \mathrm{Oe} て ゙$ の磁束密度）は $5.4 \mathrm{KG}$ で保磁力 $H_{c}$ は $2.9 \mathrm{Oe}$ であ つた. 高温焼鈍は $1100^{\circ} \mathrm{C}$ で $2 \mathrm{~h}$, 昰取焼鈍は $800^{\circ} \mathrm{C}$ 


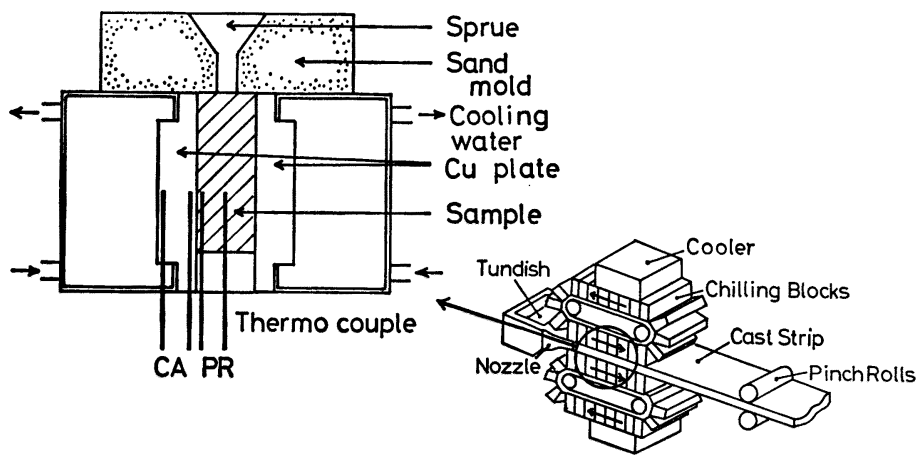

Fig. 2. Experimental apparatus.

Table 3. Chemical composition of high carbon steel $(\%)$.

\begin{tabular}{c|c|c|c|c}
\hline $\mathrm{C}$ & $\mathrm{Si}$ & $\mathrm{Mn}$ & $\mathrm{P}$ & $\mathrm{S}$ \\
\hline 0.8 & 0.35 & 0.5 & 0.03 & 0.025 \\
\hline
\end{tabular}
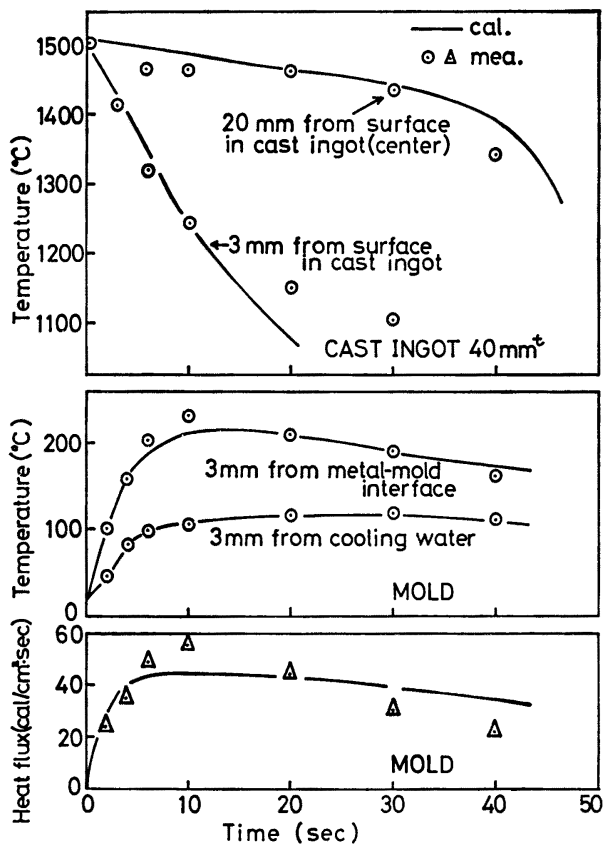

Fig. 3. Temperature of cast plate and mold.

で $2 \mathrm{~h} ，$ いずれも水素雲囲気で行つた. しかし, 磁性材 料に比較して（例えば，1\% 珪素鉄 $B_{25}=16 \mathrm{KG} H_{c}=$ $0.4 \mathrm{Oe})$ 劣つた性質となつている。この理由としては, 黒鉛が存在することか, 黒鉛が存在するために結晶粒が 粗大化されなかつたことが考えられる.

\section{3. チルブロックを用いての高炭素鋼の 急冷凝固実験}

Table 1 の I とII の研究として, $0.8 \% \mathrm{C}$ 鋼を 2 枚の
水冷銅チルブロックの間に鋳込み，鋳片の冷却特性，鋳 造組織, マクロ偏析，介在物粒径等を調査した。本実験 は Fig. 2 に示すように，チルブロック方式のキャスタ 一での冷却を想定したものである.

高炭素鋼では, 冷間圧延の前に, 熱延材のセメンタイ 卜球状化処理を必要とするので, 七メンタイトの球状化 に対する急冷効果も調查した.

\section{$3 \cdot 1$ 実験方法}

Fig. 2 は，水冷の 銅チルブロック（銅板の厚み 25 $\mathrm{mm})$ の実験装置である. $15 \mathrm{~kg}$ の高周波溶解炉を用いた 溶湯を砂型の湯道を通して上注し，銅チルブロックで急 冷凝固させた. Table 3 に化学組成を示す. 鋳込温度は $1590^{\circ} \mathrm{C}$ 一定で行つた。鋳片サイズは縌 $120 \mathrm{~mm}$, 横 70〜80 mm で，厚みは 40, 25, 10, 5, $3 \mathrm{~mm}$ である. 鋳片は銅チルブロック内で常温まで冷却した。また 40 $\mathrm{mm}$ 厚の鋳片と鋳型の測温を行い, 冷却挙動を検討し た。測温位置は，鋳型内では鋳片側及び冷却水側からそ れぞれ $3 \mathrm{~mm}$ のところである.鋳片内では，鋳片中心 部と鋳片表面から $3 \mathrm{~mm}$ のところである。

\section{$3 \cdot 2$ 実験結果と考察}

\section{$3 \cdot 2 \cdot 1$ 冷却特性}

$40 \mathrm{~mm}$ 厚の鋳片と鋳型との間の熱伝達係数を種々変 化させて，鋳片と鋳型の温度変化を計算し，実測值と比 較して熱伝達係数を求めた. 熱流の方向は, 鋳型面に垂 直な方向と考えられるため, 一次元の熱伝導計算で行つ た. 熱伝達係数を $0.06 \mathrm{cal} / \mathrm{cm}^{2} \cdot \mathrm{s} \cdot{ }^{\circ} \mathrm{C}$ とすると, Fig. 3 に示すよらに計算值と実測値が比較的一致した．鋳型内

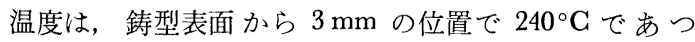
た。

上記データを用いて鋳型内の熱流束を計算したとこ ろ, 平均值として約 $40 \mathrm{cal} / \mathrm{cm}^{2} \cdot \mathrm{s}$ となり，金材技研が 双ベルト方式の Hazelett で行つた時の熱流束 ${ }^{8)}$ と同等 の值となつた。このことから，双べルト方式と本実験で 想定したチルブロック方式には鋳型の冷却能には大きな 


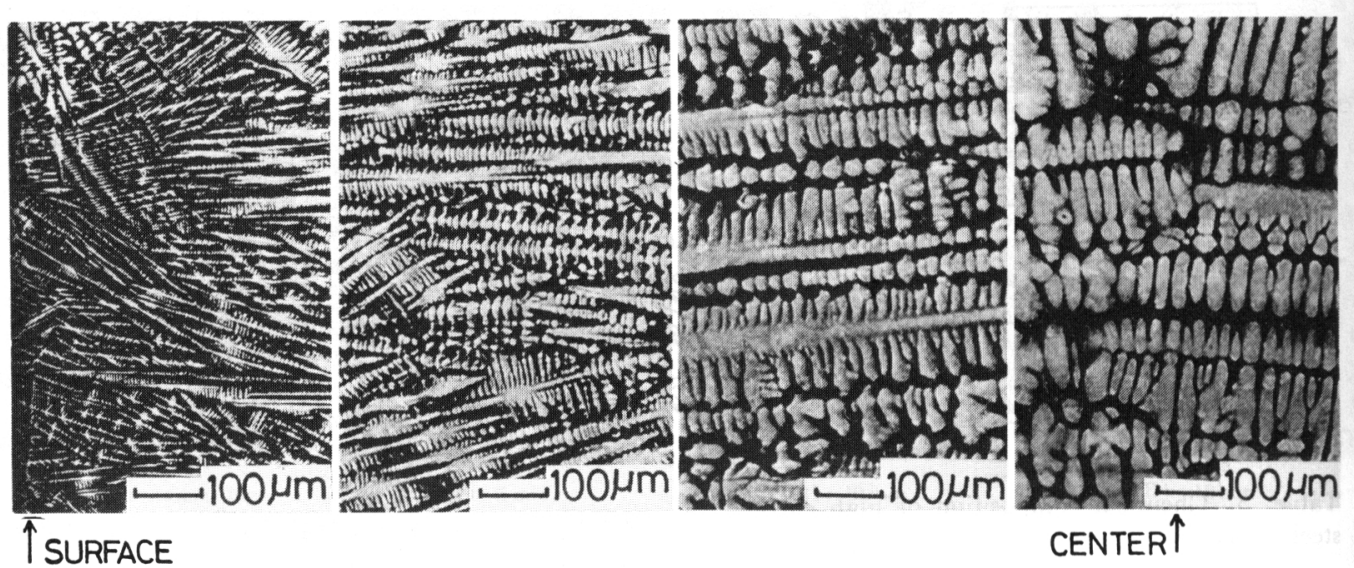

Photo. 4. Macro structure (25 mm thick cast plate).

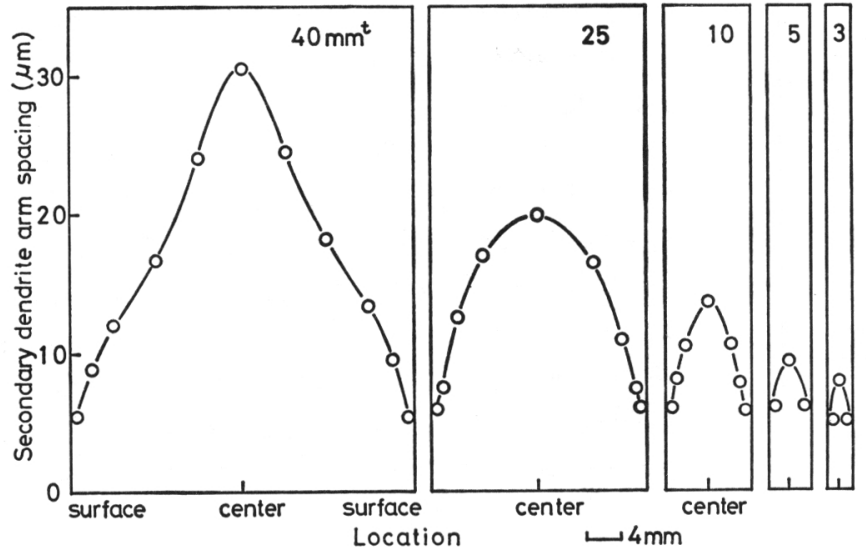

Fig. 4 Secondary dendrite arm spacing.

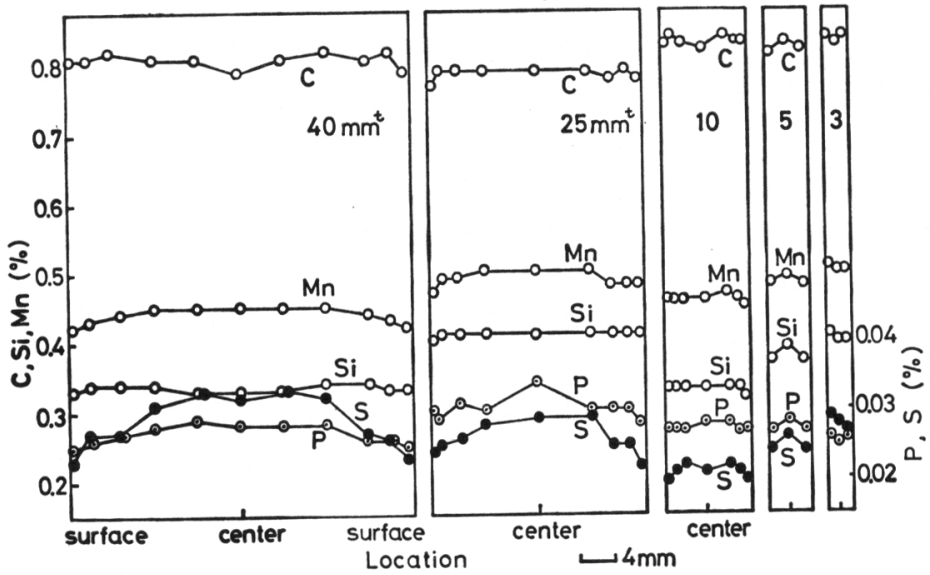

Fig. 5. Macro segregation. 


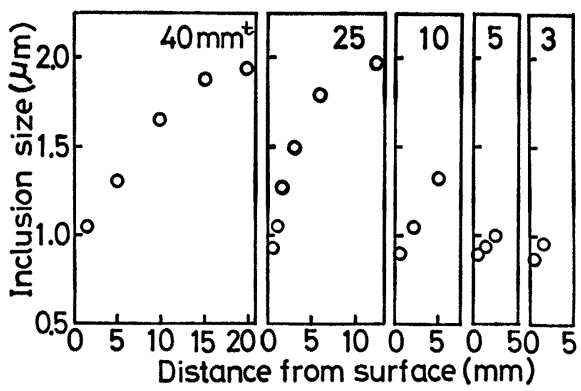

Fig. 6. Average inclusion size.

相違はないものと考えられる.

$3 \cdot 2 \cdot 2$ マクロ組織

Photo. 4 は, $25 \mathrm{~mm}$ 厚の鋳片の表面から中心へのデ ンドライト組織である. 鋳片表面から中心にかけて柱状 晶がのび, 等軸晶は存在しなかつた. 他の厚みの鋳片も すべて柱状晶であつた。 ただし，いずれの鋳片にも中心 部でキャビティーが存在することがある.

各鋳片の鋳片表面から中心までのアーム間隔の測定結 果が Fig. 4 である. 鋳片表面部が 5〜6 $\mu \mathrm{m}$ で, 鋳片 の厚みによりほとんど変化しなかつた。鋳片中心部は, 鋳片厚みの増加によりアーム間隔の増加がみられた．鈴 木ら9) により求められた次式に示すアーム間隔と冷却速 度の関係を急冷域まで払大して使用すると, 鋳片表面部 の冷却速度は $3 \times 10^{3} \sim 5.5 \times 10^{3 \circ} \mathrm{C} / \mathrm{s}$ の範用で, $40 \mathrm{~mm}$ 厚鋳片の中心部の冷却速度は $5 \times 10^{1 \circ} \mathrm{C} / \mathrm{s}$ となつた

$$
\begin{aligned}
& S=710 \cdot \mathrm{R}-0.39 \\
& S: 2 \text { 次アーム間隔 }(\mu \mathrm{m}) \\
& R: \text { 冷却速度 }\left({ }^{\circ} \mathrm{C} / \mathrm{min}\right)
\end{aligned}
$$

\section{$3 \cdot 2 \cdot 3$ マクロ偏析}

Fig. 5 は鋳片厚み $25 \mathrm{~mm}$ の時の $\mathrm{C}, \mathrm{Si}, \mathrm{Mn}, \mathrm{P}, \mathrm{S}$ の鋳片厚み方向でのマク口偏析を示したものである. 図 中の分析值は, カウントバック分析による. Fig. 5 で 特徵的なことは, 鋳片内で偏析が軽微であつたことであ る. C, Si, Mn についてはいずれの鋳片厚みでも偏析 が少なく，Pと Sについては $40 \mathrm{~mm}$ と $25 \mathrm{~mm}$ で若干 の偏析がみられた程度である.これは鋳片が薄いために 冷却速度が大きく, デンドライトが微細で, 濃化溶鋼の 流動が起こりにくかつたためと考えられる。

\section{$3 \cdot 2 \cdot 4$ 介在物}

鋳片表面から中心にかけて微細な介在物が観察され た. Fig. 6 は, $40 \mathrm{~mm}$ から $3 \mathrm{~mm}$ までの各鋳片の表面 から中心への平均介在物粒径の変化を示している．表面 に比較して中心では粒径が大きくなる傾向がある．表面 では，0.5〜1 $\mu \mathrm{m}$ の介在物が多いが，中心に向からにつ
れて 0.5 1 $\mu \mathrm{m}$ の介在物が減少し, $3 \mu \mathrm{m}$ 以上の介在 物が増加する. 介在物は $\mathrm{MnS}$ が多く, $\mathrm{MnS}$ の存在位 置はデンドライト樹間であつた.

2 次のデンドライトアーム間隔は冷却速度に依存して おり，また $\mathrm{MnS}$ の平均粒径も冷却速度に依存している ので, $\mathrm{MnS}$ の平均粒径と 2 次アーム間隔の関係も求め られる，例えば低合金鋼では，次式の関係があり 10)11， 2 次アーム間隔が小さくなると, $\mathrm{MnS}$ の平均粒径も小 さくなる.

$d=0.034 \times S_{\text {II }}+0.8$

$d$ : 平均粒径 $(\mu \mathrm{m}) \quad S_{I I}: 2$ 次アーム間隔 $(\mu \mathrm{m})$

本実験での冷却速度域では, 鋳片表面の 2 次アーム間隔 は 5 6 $\mu \mathrm{m}$ であるので, $\mathrm{MnS}$ の平均粒径は約 $1 \mu \mathrm{m}$ となる.また $40 \mathrm{~mm}$ 鋳片の中心部は，2次アーム間隔 が $40 \mu \mathrm{m}$ であるので, $\mathrm{MnS}$ の平均粒径は $2.2 \mu \mathrm{m}$ と なる.これらの数値は, Fig. 6 の平均粒径の測定結果 とよく一致している.

\section{$3 \cdot 2 \cdot 5$ 七メンタイト組織の球状化}

Photo. 5 は, Fig. 2 の実験で得られた $5 \mathrm{~mm}$ 厚の鋳 片と $40 \mathrm{~mm}$ 厚の鋳片（中心部の $5 \mathrm{~mm}$ の部分を切り出 して調査）を $690^{\circ} \mathrm{C} て ゙ 20 \mathrm{~h}$ まで焼鈍したミク口組織 である、焼鈍前のミクロ組織は $5 \mathrm{~mm}$ の場合が微細パ ーライトで, $40 \mathrm{~mm}$ の場合はややあらいパーライトで ある. $5 \mathrm{~mm}$ 鋳片では $1 \mathrm{~h}$ の焼鈍でかなり球状化が行わ れ，20h ではほぼ完全に 球状となつている. 一方 40 $\mathrm{mm}$ の鋳片の中心部では, $1 \mathrm{~h}$ では部分的に球状化が始 まつているが, $20 \mathrm{~h}$ でもラメラー状のパーライトが残留 している. $5 \mathrm{~mm}$ の鋳片は急冷凝固に引き続いて共析変 態の泠却速度がはやいため, $40 \mathrm{~mm}$ 鋳片の中心部よりも セメンタイトの球状化がはやくなつた. $5 \mathrm{~mm}$ よりさら に薄鋳片とするか，共析変態の泠却速度を高めることに よつてベーナイト組織にすれば，七メンタイトの球状化 時間短縮にはより有効となろう。

また，急冷凝固で常温まで冷却した鋳片を $1200^{\circ} \mathrm{C}$ に再加熱して熱延するプロセスを想定した実験では，七 メンタイトの球状化には急冷凝固時の効果はあらわれ ず，熱延後の冷却速度の影響が強くあらわれることを確 認した。

以上の結果から，球状セメンタイト鋼板を簡略に作製 するプロセスを提案することができる．溶湯から双ロー ル等で直接数 $\mathrm{mm}$ の鋳片を作製し， 2 次冷却ゾーンを もうけて共析変態域を急冷する. その後共析変態直下で 保温して球状化を行い, 溶湯から球状セメンタイト鋼板 を連続的に作製する方法である.

$3 \cdot 2 \cdot 6$ 熱延にともならデンドライト組織の変化 


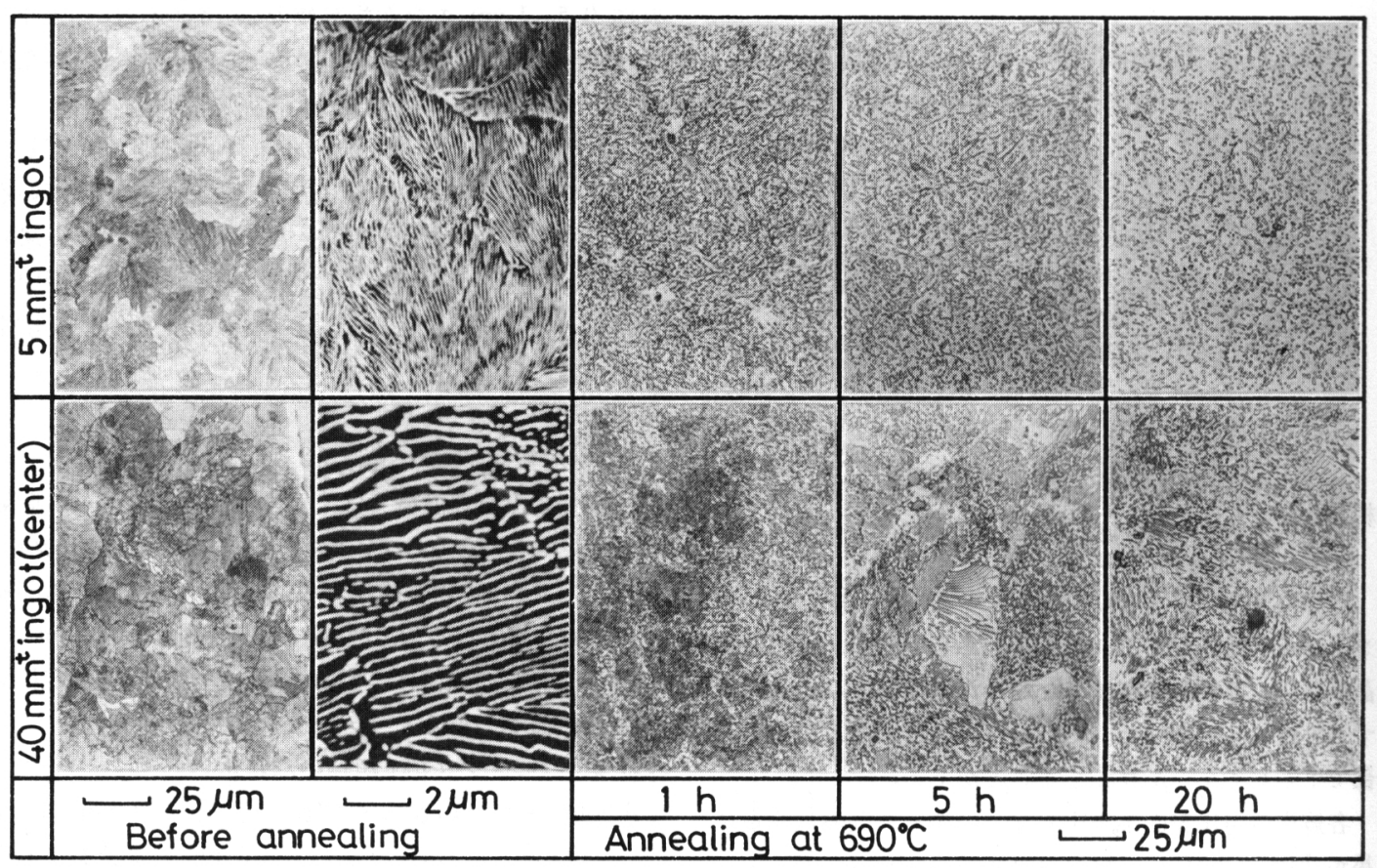

Photo. 5. Spheroidization of cementite structure.

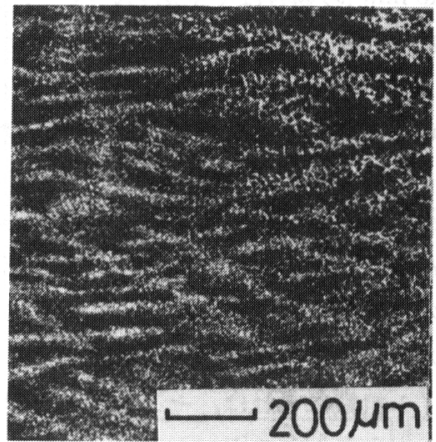

Reduction ratio 2

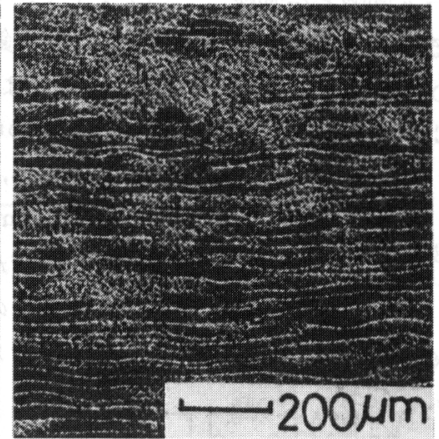

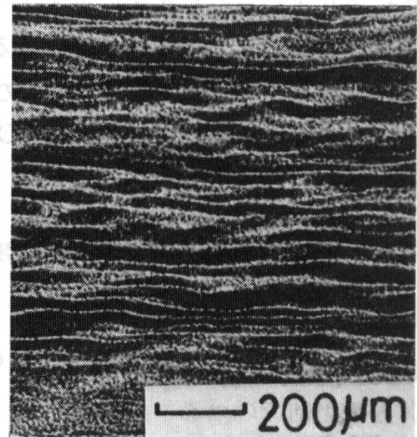

4

Photo. 6. Change of dendrite structure with reduction.

急冷凝固プロセスでは, いずれの方式でも現行の連鋳 よりも鋳片厚みが薄くなり，大きな圧下比はとれなくな る. 急冷凝固した鋳片では, 圧下比 ${ }^{1213)}$ 之材質の関係や デンドライトの消失との関係を調べることは圧延工程と のマッチングからも重要である.

本実験では, 常温まで急冷凝固した $40 \mathrm{~mm}$ 厚の鋳片 を再び $1200^{\circ} \mathrm{G} て ゙ ~ 1 \mathrm{~h}$ 加熱した後, 仕上圧延温度 900 ${ }^{\circ} \mathrm{G}$ で熱延した. Fig. 7 は圧下比にともなら圧延方向の 引張強度とのびの変化である. 圧下比は初期厚みと圧延 後の厚みの比率で示した. 強度は圧下比によりあまり変
化していないが，のびは压下比が大きくなるとばらつき が小さくなり, のびも大きくなる. Photo. 6 は圧下比 にともならデンドライト組織の変化である. 撮影位置 は, 圧延材厚み方向の表面と中心の中間である. 圧下比 を 3 以上にするとデンドライトが見かけ上消失する. こ れは Fig. 7 の機械的性質の変化と対応している. 牛 島 ${ }^{14)}$ は, 現行のスラブ連鋳片での必要最小圧下比を 3 5 としているが，急冷凝固を利用したプロセスの場合に も 3 以上の圧下比が必要である. 


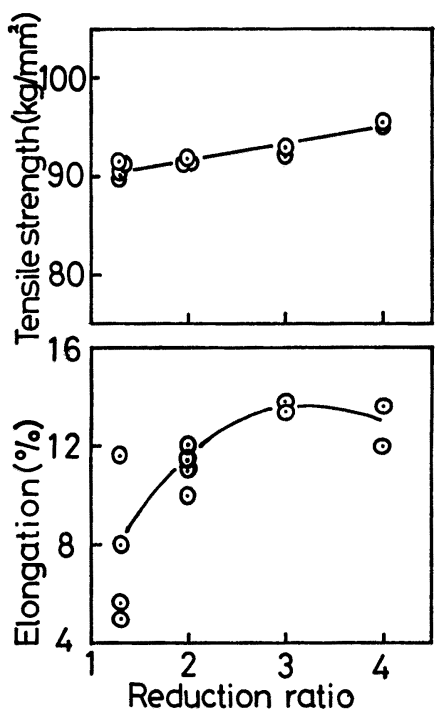

Fig. 7. Change of mechanical property with reduction.

\section{4. 結言}

実験室規模の双ロール法により $1 \sim 2 \mathrm{~mm}$ 厚の球状黒 鉛鋳鉄薄板を作製し, 凝固組織と冷間圧延と圧延材の性 質について調查した. 得られた結果は次のようにまとめ られる.

(1)双ロール法で溶湯は急冷凝固されるためセメンタイ トとオーステナイトの共晶である白銑組織となる.デン ドライトの 2 次アーム間隔は鋳片表面部で $7 \mu \mathrm{m}$ で, 2 次アーム間隔と冷却速度の関係を急冷域まで拡大して用 いると, 冷却速度は約 $10^{3} \mathrm{C} / \mathrm{s}$ となつた。

(2)双ロール法で得られた白銑組織は短時間の焼鈍で黒 鉛組織に変態する.

(3)黒鉛化焼鈍した鋳片は冷間圧延が可能であつた. 急 冷凝固とその後の黒鉛化焼鈍により微細黒鉛とフェライ ト組織となるためである.

(4)冷延材は容易に曲げることができる. 冷延材の磁気 的性質を測定したが，磁性材料並みの性質は得られなか つた.

次にチルブロックキャスターを想定して，2枚の水冷 銅チルブロックの間に $40 \mathrm{~mm}, 25 \mathrm{~mm}, 10 \mathrm{~mm}, 5 \mathrm{~mm}$, $3 \mathrm{~mm}$ の高炭素鋼を鋳込及急冷凝固させた. 鋳片の冷却 特性, 凝固組織, マクロ偏析, 介在物, 七メンタイトの
球状化，熱延に拈ける必要圧下率について調査した。得 られた結果は次のよらにまとめられる。

(5)チルブロック方式の 冷却特性を調査した 結果, 40 $\mathrm{mm}$ 厚鋳片の場合で, 鋳型内熱流束は約 $40 \mathrm{cal} / \mathrm{cm}^{2} \cdot \mathrm{s}$ と推定される.

(6)デンドライトの 2 次アーム間隔は鋳片表面部が 5 $6 \mu \mathrm{m}$ で鋳片の厚みの変化によりほとんど変化しなかつ た. 鋳片中心部では鋳片厚みの増加によりアーム間隔が 増加した. 2 次アーム間隔と冷却速度の関係から鋳片表 面部は $3 \times 10^{3} \sim 5.5 \times 10^{3} \mathrm{C} / \mathrm{s}$ の範囲で, $40 \mathrm{~mm}$ 厚鋳片 の中心部は $5 \times 10^{1} \mathrm{C} / \mathrm{s}$ の冷却速度となつた.

(7)急冷凝固によりマクロ偏析の軽減と介在物の微細化 の効果が得られた.

(8)共析変態域を急冷すれば微細パーライトの焼入れ組 織となるため, 短時間の熱処理で球状セメンタイト組織 を得ることができるままた，急冷凝固で常温まで冷却し た鋳片を $1200^{\circ} \mathrm{C}$ に再加熱して熱延するプロセスを想 定した実験では，七メンタイトの球状化には急冷凝固の 効果はあらわれず，熱延後の冷却速度の影響が強くあら われる。

(9) $40 \mathrm{~mm}$ 厚鋳片を用いて圧下比とデンドライト 組 織 及び機械的性質の関係を検討したところ， 3 以上の圧下 比が必要であつた.

\section{交献}

1) たとえば M.R. MOORE: Iron Steelmaker, 10 (1983) 12, p.22

2) たとえば $B . C$. Whitmore and J. W. HLINKA: J. Met., 21 (1969) 8, p.68

3) 草川隆次：鉄と鋼, 71 (1985), A200

4) 岡本平: 鋳物, 49 (1977), p.770

5) 大平五郎, 井川克也：鋳造工学 (日本金属学会編) (1971), p. 151

6) 大出卓, 大平五郎：鋳物, 44 (1972), p.199

7) 大出卓, 大平五郎: 鋳物, 42 (1970), p.913

8) 田中稔, 吉松史朗: 鉄と鋼, 69 (1983), p. 1684

9）鈴木章, 鈴木武, 長岡豊, 岩田至弘: 日本金属学 会誌, 32 (1968), p.1301

10）高田寿，別所勇，伊藤孝道：鉄と鋼, 62 (1976), p. 1319

11）高田寿：北海道大学工学部学位論文「鋼の硫化物 系非金属介在物の性状と鋼板の機械的性質に関す る研究」(1978)

12）奥村直樹，南雲道彦，井上泰，山本広一：鉄と鋼， 70 (1984), p.216

13）奥村直樹，長谷川俊永，織田昌彦，南雲道彦：鉄 と鋼, 70 (1984), p.388

14）牛島清人：第 40.41 回西山記念技術講座（日本 鉄鋼協会編) (1976), p.262 